\title{
The application of seaweed Gracilaria verrucosa in Karawang Regency, Indonesia, as enrichment material in bar soap production
}

\author{
Muhammad Fadhlullah ${ }^{1}$, Liliek Soeprijadi ${ }^{1}$, Susi Ratnaningtyas ${ }^{1}$, and Iman Mukhaimin ${ }^{1}$ \\ ${ }^{1}$ Polytechnic of Marine Affairs and Fisheries Karawang
}

April 16, 2021

\begin{abstract}
Seaweed Gracilaria verrucosa is one of the potential marine natural resource commodities in Karawang Regency, Indonesia. The $G$. verrucosa-enriched bar soap is one of the added value products that can be developed from seaweed since it has a potential antiseptic function for human skin. Also, the seaweed-enriched bar soap sale can give more incomes for the seaweed farmers and coastal community in Karawang Regency. This study aims to produce bar soap with the addition of different seaweed $G$. verrucosa formulation and to examine the sensory, physicochemical, and bioactivity characteristics of $G$. verrucosa-enriched bar soap. This study applied five variants: the bar soap with extract of water $+250 \mathrm{ppm}$ of seaweed (W250), extract of water +500 ppm of seaweed (W500), extract of water $+750 \mathrm{ppm}$ of seaweed (W750), extract of ethanol +750 ppm of seaweed (E750), and seaweed pulp (SWP). The bar soap of variant W500 has the highest attributes according to the sensory and physicochemical analysis, while the variant SWP has the highest bioactivity parameter. From the results, the bar soap of variant W500 and SWP can be the candidates for further product development.
\end{abstract}

\section{Introduction}

Seaweed, especially Gracilaria verrucosa (Fig. 1), is one of the potential marine natural resource commodities in Karawang Regency, Indonesia (Waluyo et al ., 2019). According to the publication of Karawang Regency's Central Bureau of Statistics (BPS Kabupaten Karawang), the productivity of seaweed cultivation in Karawang from 2016 - 2018 increased from 414.90 - 902.53 tonnes (BPS Kabupaten Karawang, 2017, $2018,2019)$. Usually, the harvested seaweeds are sold as dried products to the small traders and industries around Karawang. However, the price of dried seaweed is low, which is around $0.50 \mathrm{USD} / \mathrm{kg}$ (Setyaningsih et al ., 2012; Deswati and Luhur, 2014; Hikmayaniet al ., 2017; Waluyo et al ., 2019).

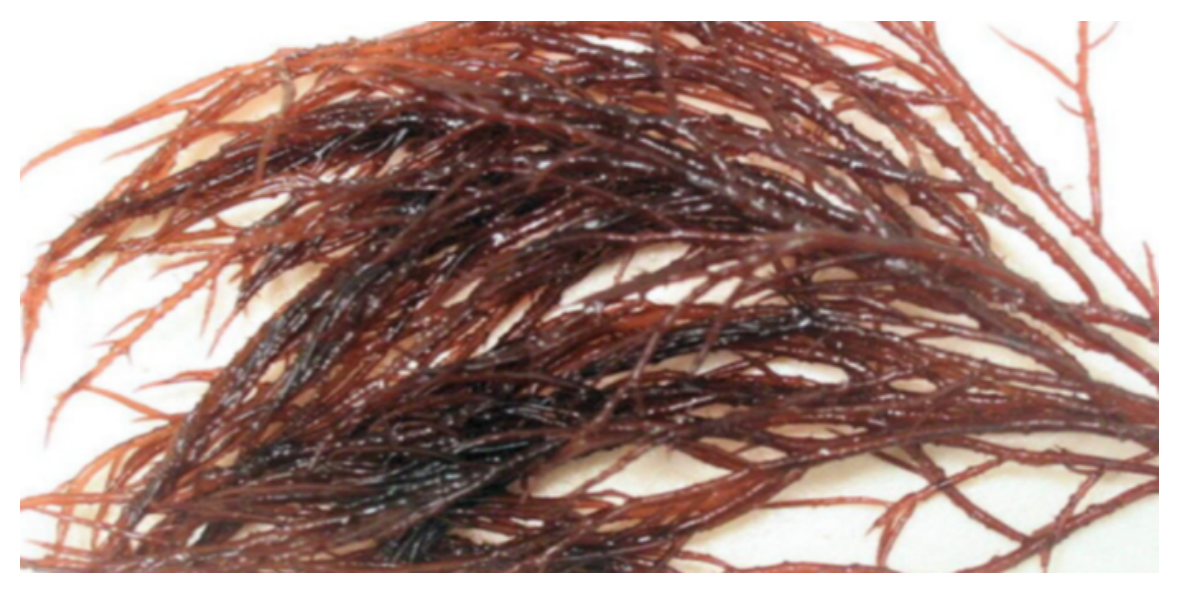


Figure 1: The appearance of seaweed Gracilaria verrucosa (Kurniasari et al., 2018).

On the other hand, many products have been developed from seaweed and traded with a higher selling price compared to the dried seaweed. The examples of added value products that have been developed from seaweed are agar extract, biofertilizer, biofuel, pharmaceutical, and cosmetic products (Kaliaperumal, 2003; de Almeida et al ., 2011; Francavilla et al ., 2013; Baehaki et al ., 2019). The variation of seaweed-based products is due to the metabolite compounds that are contained in seaweed. Seaweed contains primary metabolites such as polysaccharides (agar, alginate, carrageenan), poly-unsaturated fatty acid (PUFA), and proteins. Furthermore, seaweed also contains secondary metabolites, such as carotenoid, alkaloid, and polyphenol, which have bioactive characteristics (de Almeida et al ., 2011; Goudaet al ., 2013; Kim et al ., 2015; Waluyo et al ., 2019).

Due to the bioactive compounds in seaweed, Rahayu (2015), Prasedyaet al . (2018), and Baehaki et al . (2019) have devised an experiment to study the potential of seaweed Eucheuma cottoniiand Sargassum sp. as additional material to produce soap. It was shown that the bioactive compounds contained in seaweed, such as phenolic compounds, promoted the anti-bacterial activity on the skin. Furthermore, Maftuch et al. (2016) have investigated that the extract of seaweed G. verrucosa has anti-bacterial activity against Aeromonas hydrophila, Pseudomonas aeruginosa andPseudomonas putida due to the content of alkaloid, flavonoid, tannin, and phenolic compounds. Those previous research, thus, become the foundation of this study, which is to apply seaweed $G$. verrucosa as additional material to produce bar soap.

There are various reasons that the development of bar soap enriched with $G$. verrucosa as seaweed added value products in this study is considered potential. First, the primary material to produce bar soap is easy to obtain, and the making process of bar soap is simple. Bar soap can be produced due to the saponification reaction, which is the reaction between fats or oils and caustic soda (Fig. 2). Second, since the seaweed G. verrucosa is produced locally in Karawang Regency, the resulting bar soap can be branded as the local product or local souvenir of Karawang Regency. Last, seaweed-enriched bar soap can be sold at a higher price compared to dried seaweed. As a reference, bar soap enriched with lemongrass (Cymbopogon citratus ), which is another natural material, was priced around 1 USD/bar of soap (Mahyatiet al ., 2018). If it is assumed that the net weight of 1 bar of soap is $100 \mathrm{~g}$, then the price of the bar soap is around $10 \mathrm{USD} / \mathrm{kg}$. Therefore, the seaweed farmers or coastal community in Karawang Regency are potentially able to gain more incomes if they sell the seaweed-enriched bar soap compared to the dried seaweed.

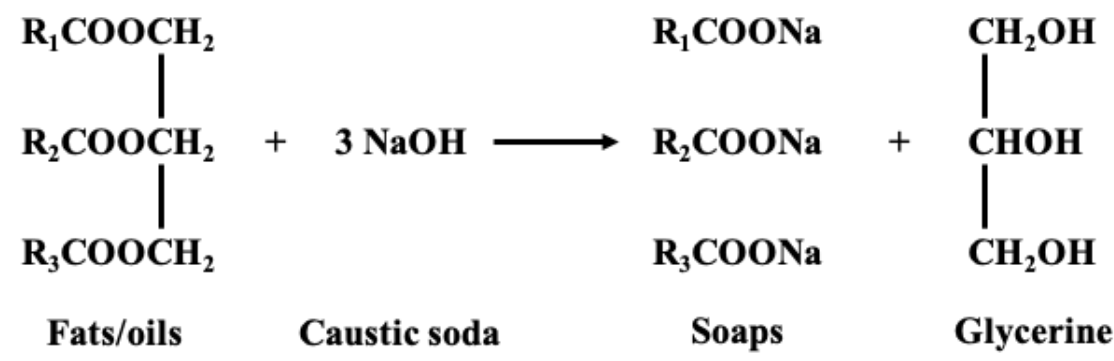

Figure 2: Saponification reaction to make soap (Hall, 2016).

However, to the authors' knowledge, the study of bar soap production enriched with seaweed G. verrucosa is not available. Before this information can be transferred to the public, preliminary research regarding the formulation and quality of seaweed G. verrucosa -enriched bar soap must be carried out. The quality of the bar soap should at least meet the Indonesian National Standard requirement, SNI 3532:2016 (Badan Standardisasi Nasional, 2016). Hence, this study aims to produce bar soap with the addition of different seaweed $G$. verrucosa formulation and to examine the sensory, physicochemical, and bioactivity characteristics of $G$. verrucosa -enriched bar soap. 


\section{Materials and methods}

\section{Experimental design}

The parameters that were observed in this study are sensory, physicochemical, and bioactivity characteristics of bar soap that is enriched with seaweed $G$. verrucosa pulp and extract. This study applied five variables and two controls with two replications. The variants were bar soap with extract of water $+250 \mathrm{ppm}$ of seaweed (W250), extract of water $+500 \mathrm{ppm}$ of seaweed (W500), extract of water +750 ppm of seaweed (W750), extract of ethanol $+750 \mathrm{ppm}$ of seaweed (E750), and seaweed pulp (SWP). The controls were bar soap without any addition (C1) and commercial antiseptic bar soap (C2). In the next part, each variant and control will be mentioned by its code. The data were analyzed by using a descriptive method.

\section{Seaweed sample}

Seaweed G. verrucosa samples were acquired from Tirtajaya District, Karawang Regency, West Java, Indonesia. The seaweed samples were cleaned through immersing in clean water and then dried on room temperature for 24 hours (Wang et al ., 2008).

Making of seaweed pulp

The seaweed pulp was made through modification of the method by Hwanget al . (2010) and Tanjung et al . (2020). Seaweed samples (100 g) were dipped in $1 \mathrm{~L}$ of distilled water $(1: 10 \mathrm{w} / \mathrm{v})$ and boiled $\left(100^{\circ} \mathrm{C}\right)$ for 30 minutes. The seaweed samples were then cooled in room temperature and turned to seaweed pulp by using a blender.

Extraction of seaweed

The extraction of seaweed was adapted from Hwang et al . (2010), Widyasanti et al . (2016), and Baehaki et al . (2019), which is a maceration method. The extraction applied two different solvent, distilled water and ethanol $70 \%$. The weight of seaweed samples that were extracted for each variable are shown in Table 1 , which is based on the total weight of oil that was used to produce bar soap ( $500 \mathrm{~g})$. The seaweed samples were immersed in each solvent and then heated for 30 minutes at $100^{\circ} \mathrm{C}$ for water solvent and $60-70^{\circ} \mathrm{C}$ for ethanol solvent. The resulting filtrate solution was then separated from the solid cakes by using a filter paper.

Table 1: The weight of seaweed samples and solvent used for the extraction.

\begin{tabular}{lllll}
\hline Extraction components & W250 & W500 & W750 & E750 \\
\hline Seaweed sample $(\mathrm{g})$ & 0.125 & 0.250 & 0.375 & 0.375 \\
Distilled water $(\mathrm{g})$ & 171 & 171 & 171 & - \\
Ethanol $70 \%(\mathrm{~g})$ & - & - & - & 171 \\
\hline
\end{tabular}

\section{Production of seaweed-enriched bar soap}

The formulation of seaweed-enriched bar soap was adapted from Baehakiet al . (2019) and is shown in Table 2. The formulation was based on the cold process method and also supported by soap making application "Lye Calculator" (Bramble Berry Inc., 2019; Moloka Farm Living, 2019). The soap making process began with the mixing of palm oil and coconut oil. At the same time, a $\mathrm{NaOH}$ solution was prepared by dissolving $\mathrm{NaOH}$ crumbles in distilled water. The oil mixture then mixed with the $\mathrm{NaOH}$ solution by using a blender for $\pm 5-10$ seconds so that the trace phase is achieved. The trace phase is a condition where the oil and $\mathrm{NaOH}$ solution is entirely mixed, which is indicated by vla-like color and texture.

During the making of bar soap that enriched with seaweed pulp, the seaweed pulp and the essential oil were added to the soap right just after the trace phase was reached. The seaweed pulp, essential oil, and the soap were mixed by using a blender for $\pm 3-5$ seconds. As for the making of bar soap with the enrichment of 
seaweed extract, the $\mathrm{NaOH}$ solution was prepared by dissolving the $\mathrm{NaOH}$ crumbles in the seaweed extract solution. The essential oil was also added to the soap just after the trace phase was achieved.

The soap mixture, still in a semi-liquid form, was transferred to a soap mold. The soap mixture inside the mold was then homogenized to release air bubbles that can create holes in the final product. The bar soap was solidified after two days of storage under the open condition and room temperature.

Table 2: The formulation of seaweed-enriched bar soap.

\begin{tabular}{lllllll}
\hline Soap composition & Variants & Variants & Variants & Variants & Variants & Variants \\
\hline & C1 & W250 & W500 & W750 & E750 & SWP \\
Palm oil (g) & 250 & 250 & 250 & 250 & 250 & 250 \\
Coconut oil (g) & 250 & 250 & 250 & 250 & 250 & 250 \\
Distilled water (g) & 171.01 & - & - & - & 171.01 & 171.01 \\
NaOH crumbles (g) & 76.47 & 76.47 & 76.47 & 76.47 & 76.47 & 76.47 \\
Seaweed pulp (g) & - & - & - & - & - & $50^{*}$ \\
Seaweed extract W250 (g) & - & 171.01 & - & - & - & - \\
Seaweed extract W500 (g) & - & - & 171.01 & - & - & - \\
Seaweed extract W750 (g) & - & - & - & 171.01 & - & - \\
Seaweed extract E750 (g) & - & - & - & - & 171.01 & - \\
Essential oil** (g) & - & 5 & 5 & 5 & 5 & 5 \\
\hline
\end{tabular}

Notes: The bar soap formulation is based on $500 \mathrm{~g}$ of the oil mixture

*The seaweed pulp's weight is $10 \%$ of the oil mixture (Baehaki et al ., 2019)

**The essential oil's weight is $1 \%$ of the oil mixture

Sensory analysis

The sensory analysis that was carried out is based on the hedonic and irritation parameter test. The test was adapted from Ismanto et al . (2016) and Widyasanti et al . (2016). The test involved 11 untrained panelists in evaluating the texture, aroma, color, amount of foam, and power of detergency of the samples. The previous parameters were scored between 1 (more unpreferable), 2 (unpreferable), 3 (preferable), and 4 (more preferable). Furthermore, the irritation parameter was scored between 0 (non-irritant) and 1 (irritant). The data were then processed based on the percentage of scores 3 and 4 for the hedonic parameters and 1 for the irritation parameter.

\section{Physicochemical parameters analysis}

The physicochemical parameters analysis constituted of total fat, unsaponifiable fat, $\mathrm{pH}$, and stability of the foam. The total fat and unsaponifiable fat analysis were carried out by the third-party laboratory, PT. Saraswanti Indo Genetech, Bogor, Indonesia. The analysis was performed based on the method of Indonesian National Standard for bar soap, SNI 3532:2016 (Badan Standardisasi Nasional, 2016).

The $\mathrm{pH}$ of the samples was measured according to Baehaki et al . (2019). Bar soap samples (5 g) were dissolved in $10 \mathrm{ml}$ of distilled water and then measured by using a Universal $\mathrm{pH}$ indicator strip (Merck, Germany). The measurement of foam stability was measured based on Baehaki et al . (2019). Bar soap samples $(0.5 \mathrm{~g})$ were dissolved in $4.5 \mathrm{~mL}$ of distilled water $(1: 9 \mathrm{w} / \mathrm{v})$ in a test tube. The sample was then mixed for 1 minute and then let it still for 15 minutes. The stability of foam was then measured according to Equation 1.

The stability of foam $(\%)=\frac{b}{a} \times 100(1)$ 
where $\mathrm{a}$ is the height of foam after the mixing $(\mathrm{cm})$ and $\mathrm{b}$ is the height of foam after the 15 minutes of still condition.

\section{Bioactivity analysis}

The bioactivity analysis was carried out according to the method of Razarinah et al . (2018) and Baehaki et al . (2019). This analysis was performed by the third-party laboratory, the Aquaculture Production Business Service Center (Balai Layanan Usaha Produksi Perikanan Budidaya), Karawang, Indonesia. The bioactivity of the sample was tested against Staphylococcus aureus, a Gram-positive bacterium.

The bioactivity of the sample was indicated by the inhibition of bacterial growth, which is measured by the Kirby Bauer disc diffusion method. Agar media $(15 \mathrm{~mL})$ was poured to a sterile petri dish, and liquid bacteria culture $(10 \mu \mathrm{L})$ was spread on the agar media. Moreover, disc papers were dipped separately in distilled water (negative control), amoxicillin (positive control), and sample solutions for 2 minutes each. The disc papers were then put on the agar media that contains the testing bacteria in the petri dish. The petri dish was incubated for 24 hours at a temperature of $37^{\circ} \mathrm{C}$. The bioactivity was then measured according to the resulting inhibition/clear zone diameter, which is then converted to inhibition index (Equation 2).

Inhibition index $=\frac{\text { clear zone diameter }- \text { disc paper diameter }}{\text { disc paper diameter }}(2)$

\section{Results}

Bar soap variants

The bar soap variants that were produced in this study are shown in Fig. 3.

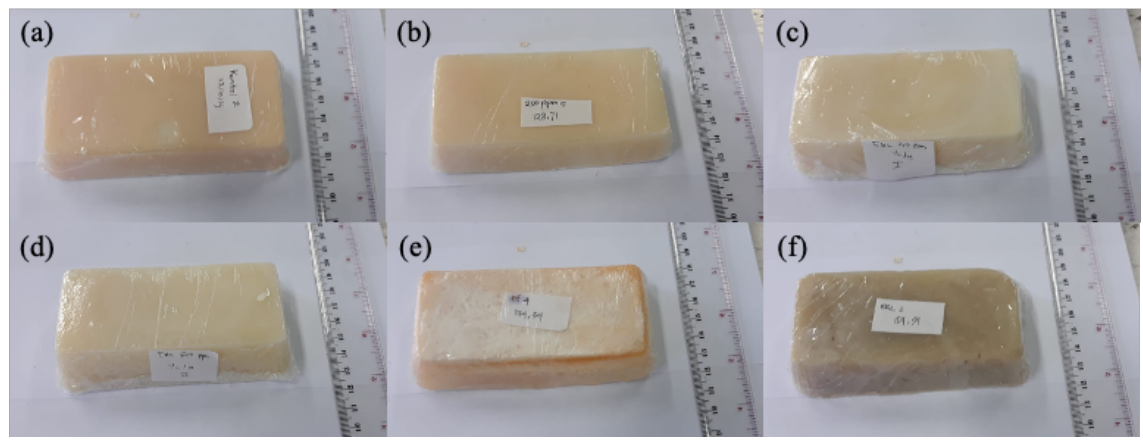

Figure 3: Bar soap variants: (a) C1 bar soap. (b) W250 bar soap. (c) W500 bar soap. (d) W750 bar soap. (e) E750 bar soap. (f) SWP bar soap.

\section{Sensory analysis}

The result of the hedonic and irritation test is shown in Fig. 4 and Table 3, respectively. 


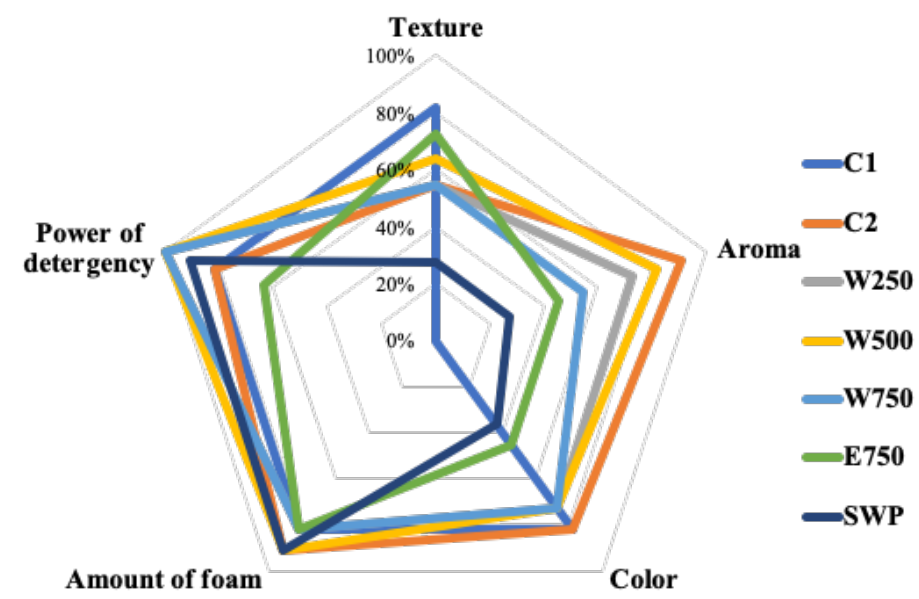

Figure 4: The result of the hedonic test on the texture, aroma, color, amount of foam, and power of detergency of bar soap variants.

As can be seen in Figure 4, the most preferred texture is bar soap of variant E750 (72.7\%), followed by variant W500 (63.6\%), W250 and W750 (54.5\%), and SWP (27.3\%). However, control bar soap (C1) has more texture preference (81.8\%) compared to bar soap of variant E750. Moreover, the commercial antiseptic bar soap (C2) has the same texture preference with variant W250 and W750.

Bar soap with the most preferred aroma is bar soap of variant W500 (81.8\%), followed by variant W250 $(72.7 \%)$, W750 (54.5\%), and E750 (45.5\%). The least preferred aroma is bar soap of variant SWP (27.3\%). For comparison, control bar soap (C1) has $0 \%$ aroma preference, while the commercial antiseptic bar soap (C2) has $90.9 \%$ preference, higher than the seaweed-enriched bar soaps.

Bar soap of variant W250, W500, and W750 has the same color preference (72.7\%), followed by variant E750 (45.5\%) and SWP (36.4\%). On the other hand, the control bar soap (C1) and the commercial antiseptic bar soap (C2) has $81.8 \%$ color preference. The color preference of $\mathrm{C} 1$ and $\mathrm{C} 2$ bar soap is also higher compared to the seaweed-enriched bar soaps.

For the amount of foam parameter, bar soap of variant W500 and SWP have the highest preference value (90.9\%). Bar soap of variant W250, W750, and E750 then follow with the preference value of $81.8 \%$. The preference value of the seaweed-enriched bar soaps is comparable with the control $(\mathrm{C} 1)$ and commercial antiseptic (C2) bar soap, which is $81.8 \%$ and $90.9 \%$, respectively.

As for the power of detergency parameter, bar soap of variant W250, W500, and W750 have the preference value of $100 \%$. This is followed by bar soap of variant SWP (90.9\%) and variant E750 (63.6\%). The control (C1) and commercial antiseptic (C2) bar soap have the same preference value, $81.8 \%$.

Table 3: The result of the irritation test of the bar soap variants.

\begin{tabular}{ll}
\hline Bar soap variants & Irritation value (\%) \\
\hline C1 & 0 \\
C2 & 0 \\
W250 & 0 \\
W500 & 9
\end{tabular}




\begin{tabular}{ll}
\hline Bar soap variants & Irritation value (\%) \\
\hline W750 & 36 \\
E750 & 27 \\
SWP & 9 \\
\hline
\end{tabular}

As shown in Table 3, the panelists regarded bar soap of variant W250 as non-irritant (0\%). The irritation value then is followed by variant W500 and SWP (9\%), E750 (27\%), and W750 (36\%). Moreover, the control (C1) and commercial antiseptic (C2) bar soap were also regarded as non-irritant (0\%).

\section{Physicochemical parameters analysis}

The result of $\mathrm{pH}$, foam stability, total fat, and unsaponifiable fat analysis is shown in Fig. $5-8$, respectively.

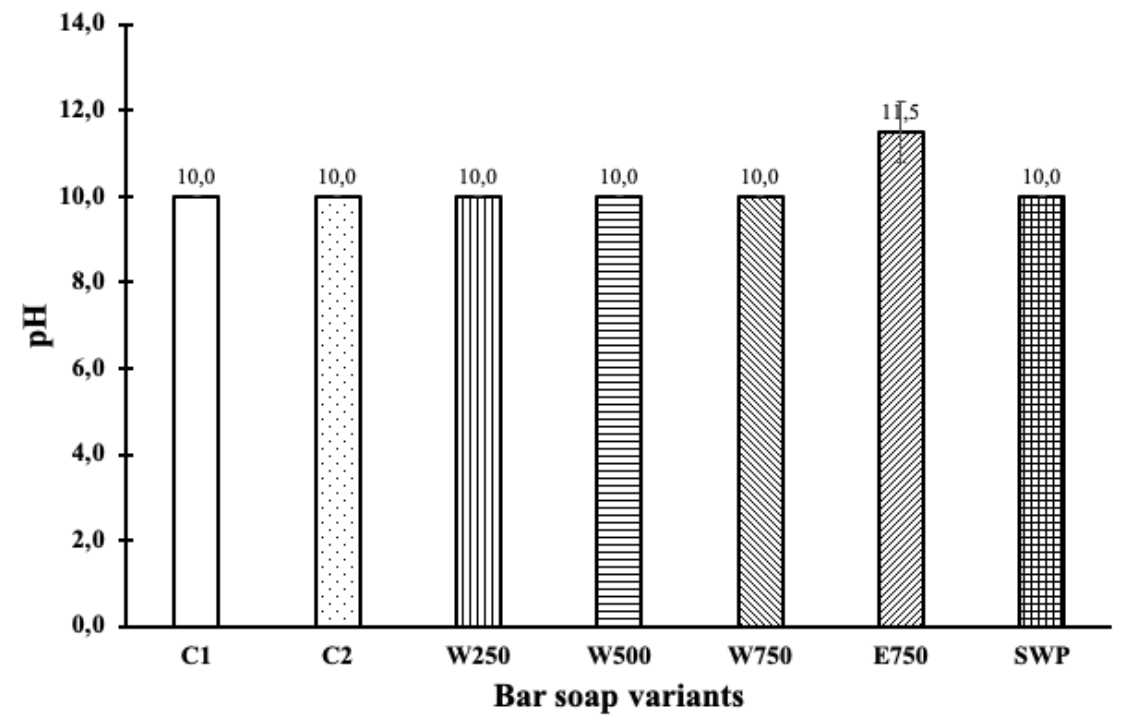

Figure 5: $\mathrm{pH}$ of the bar soap variants.

It can be seen in Fig. 5 that almost all of the bar soap variants have a $\mathrm{pH}$ of 10.0, except bar soap of variant E750 which has a $\mathrm{pH}$ of 11.5. As a comparison, the $\mathrm{pH}$ of the control (C1) and commercial antiseptic (C2) bar soap is also 10.0 . 


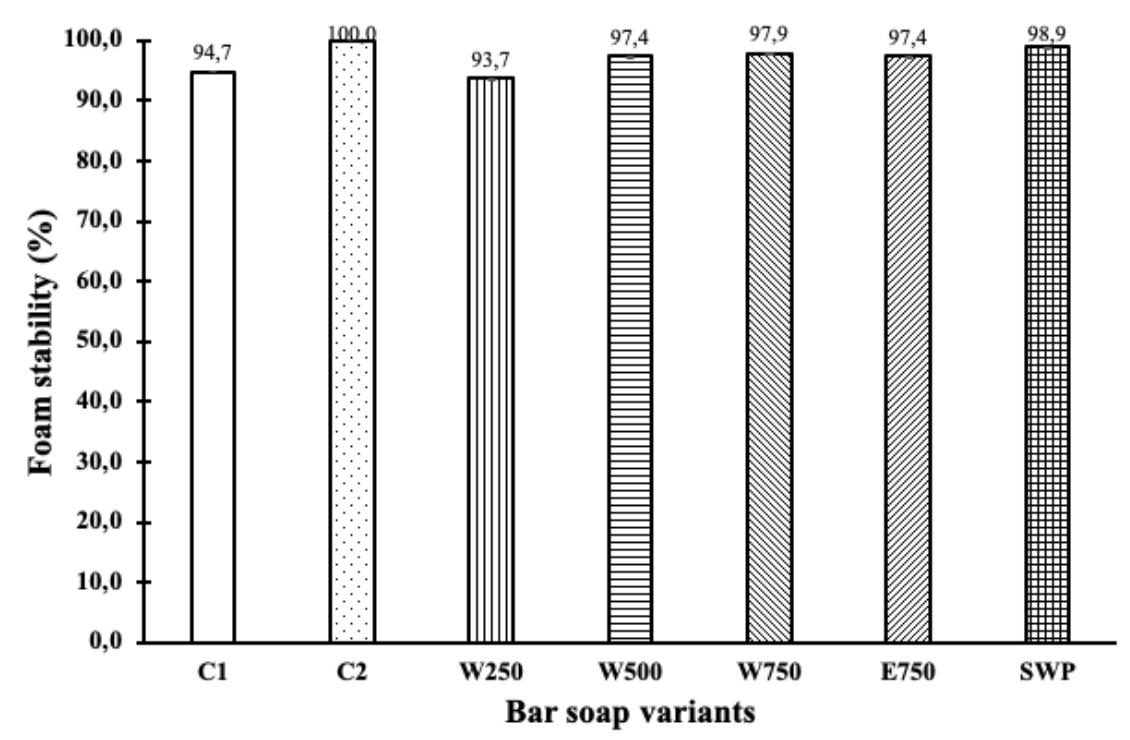

Figure 6: Foam stability of the bar soap variants.

Fig. 6 shows that the foam stability of the bar soap variants is in the range between $93.7-98.9 \%$. The bar soap of variant SWP has the highest foam stability (98.9\%), followed by variant W750 (97.9\%), variant W500 and E750 (97.4\%), and variant W250 (93.7\%). As a comparison, the control (C1) and commercial antiseptic bar soap (C2) have foam stability of $94.7 \%$ and $100 \%$, respectively.

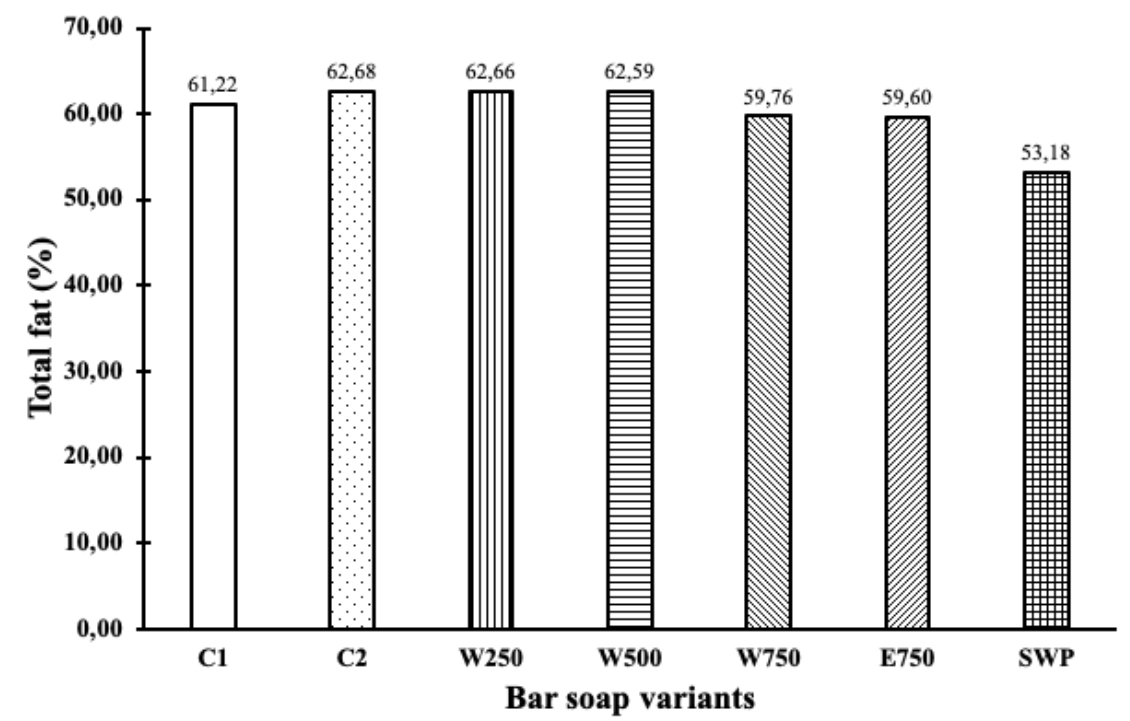

Figure 7: Total fat content of the bar soap variants.

As can be seen in Fig. 7, the highest total fat content is possessed by the bar soap of variant W250 (62.66\%), followed by W500 (62.59\%), W750 (59.76\%), and E750 (59.60\%). The variant SWP has the lowest total fat content $(53.18 \%)$. On the other hand, the control (C1) and commercial antiseptic (C2) bar soap have a total content of 61.22 and $62.68 \%$, respectively. 


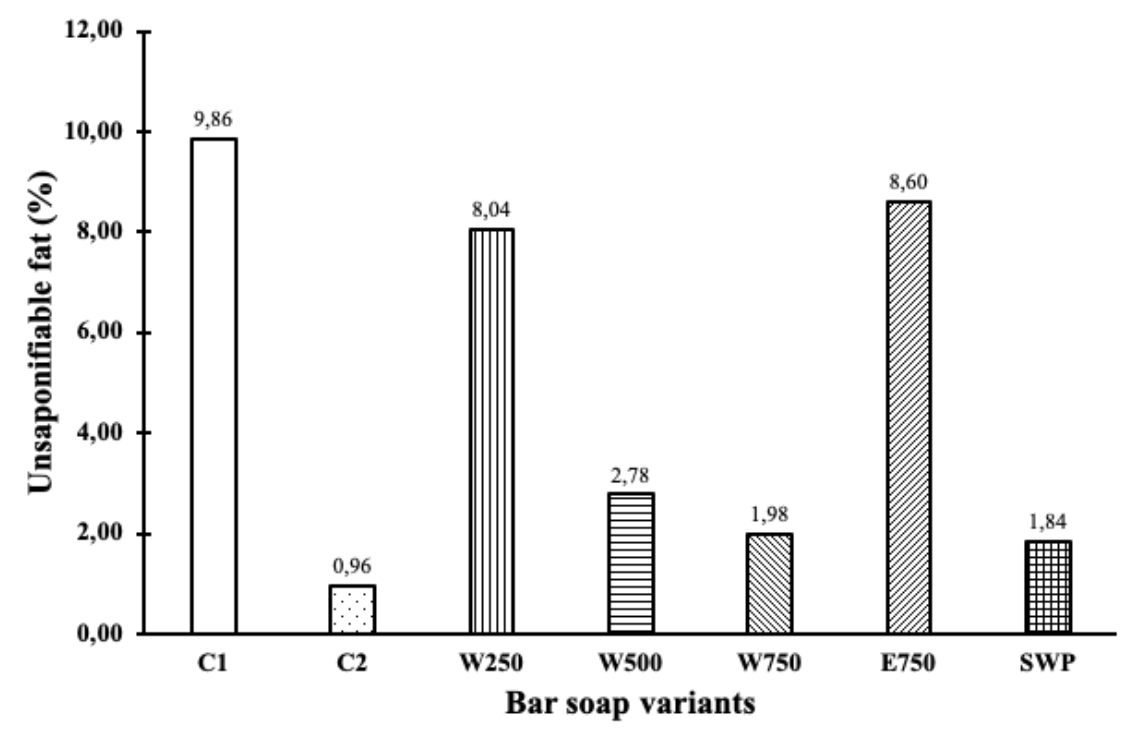

Figure 8: Total unsaponifiable fat content in the bar soap variants.

As shown in Fig. 8, the bar soap of variant E750 has the highest unsaponifiable fat content (8.60\%), then followed by variant W250 (8.04\%), W500 (2.78\%), and W750 (1.98\%). The bar soap of variant SWP has the lowest unsaponifiable fat content (1.84\%). The control (C1) and commercial antiseptic (C2) bar soap have an unsaponifiable fat content of 9.86 and $0.96 \%$, respectively.

Bioactivity analysis

The inhibition index of each bar soap variants can be seen in Fig. 9.

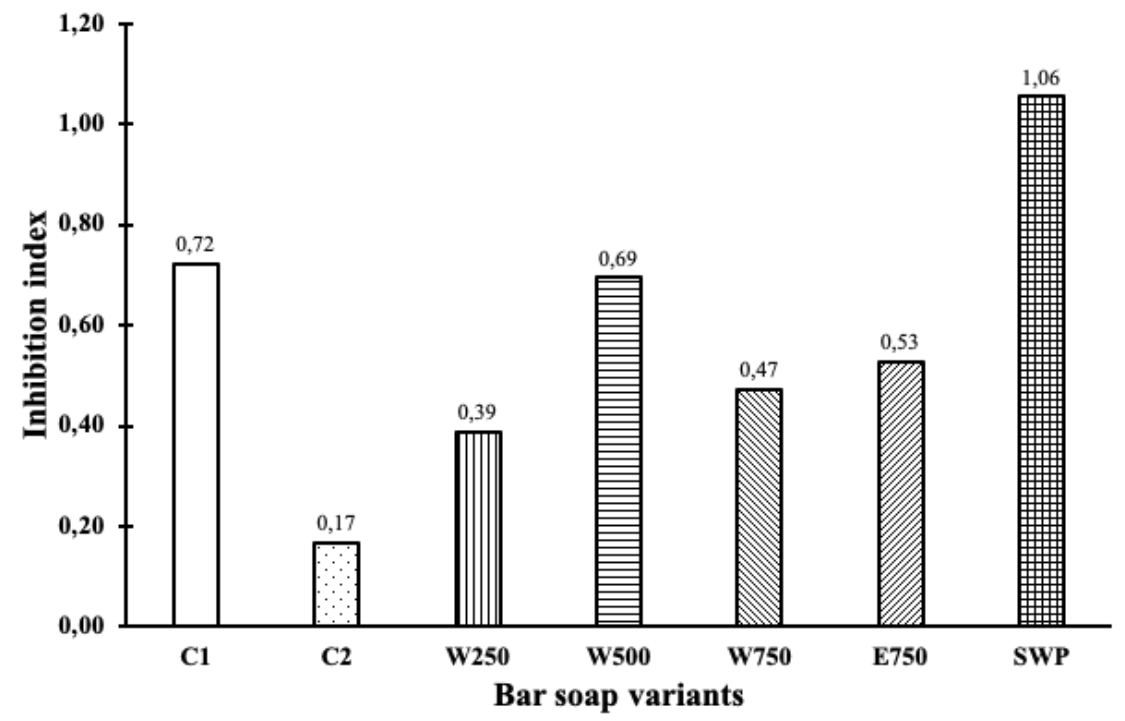

Figure 9: The inhibition index of the bar soap variants.

The bar soap of variant SWP has the highest inhibition index (1.06), followed by W500 (0.69), E750 (0.53), W750 (0.47), and W250 (0.39). Furthermore, the control bar soap (C1) has an inhibition index of 0.72, while 
the commercial antiseptic bar soap $(\mathrm{C} 2)$ has an inhibition index of 0.17 .

\section{Discussion}

\section{Sensory analysis}

The hedonic test, as part of sensory analysis, was performed to assess the reception level of the seaweedenriched bar soap that is produced in this study. The first hedonic test parameter is texture. The texture of bar soap is related to hardness and smoothness of the soap, which is affected by the composition of fatty acids. According to Baehakiet al . (2019), the suitable fatty acid composition for making bar soap is the saturated fatty acid. The saturated fatty acid does not have double bonds and has a high melting point. The saturated fatty acid will be stable at a solid-state on the room temperature, and therefore it is suitable to be used as bar soap material. In this study, the saturated fatty acid is provided by palm oil, which contains saturated fatty acid in the form of palmitic acid (Widyasanti et al ., 2016). Furthermore, the hardness of bar soap can also be affected by the water content in the soap with inverse correlation. The bar soap with higher water content has a lower hardness of texture, and so the other way around (Widyasanti et al ., 2016).

In this study, the bar soap of variant E750 has the highest texture preference perhaps due to the effect of the ethanol on the fatty acid components, and therefore on the texture of the soap. This argument comes up since each of the bar soap variants applied the same oil composition as the main material. However, this argument needs to be tested in further study, along with other tests such as water content and hardness test. On the other hand, the bar soap of variant SWP has the lowest texture preference due to that its surface is perforated and not smooth (Fig. 3f). These characteristics probably come from the seaweed pulp solid content that caused unhomogenized mixing of the soap. Therefore, it is advisable to filter the seaweed pulp first before mixing with the other soap materials.

The second hedonic test parameter is the aroma. In this study, the aroma of the bar soap variants is affected by the addition of essential oil. Each variant has the same essential oil concentration addition, yet the aroma preference value for each variant is different. The difference could occur due to different storage conditions, such as airtightness and duration. The different storage conditions, thus, caused different rates of soap aroma loss. On the other hand, the low aroma preference value possessed by the bar soap of variant SWP is possibly due to the unpleasant aroma. As stated in the previous paragraph, the variant SWP still contained organic solids, which can decompose and produce an unpleasant odor in the long term.

The third hedonic test parameter is color. The bar soap variant of W250, W500, and W750 have smooth and yellowish-white color (Fig. $3 \mathrm{~b}-\mathrm{d}$ ). The use of palm oil as one of the main materials causes the yellowish color of the soap (Hambali et al ., 2005). The bar soap of variant E750 also has a yellowish color, but the color is not well mixed (Fig. 3e). According to Bramble Berry Inc. (2016), ethanol cannot mix well with other soap materials. Therefore, the making of bar soap that applies ethanol requires a different method. Moreover, the variant E750 has a part with crystal color, which is possibly due to the interaction between ethanol and other soap components (Baehaki et al ., 2005). Then, the bar soap of variant SWP has a dark color that could also be caused by the solid content (Fig. 3f). Hence, this condition also urges the filtering of the seaweed pulp before applying in soap production.

The fourth hedonic test parameter is the amount of foam. The amount of foam became one of the hedonic test parameters due to the general perception that the amount of foam is proportional to the quality of the soap. However, the amount of foam does not correlate with the cleaning performance of the soap. The amount of foam is related to the active compounds contained in the soap, such as fatty acids and surfactants. The active compounds from the seaweed could also possibly affect the amount of foam that is produced by the soap (Widyasari, 2010; Karo Karo, 2011).

The final hedonic test parameter is the power of detergency. The power of detergency of the soap is supported by the chemical structure of the soap. Soap molecules have a lipophilic carbon chain that can dissolve oil and fat, and also hydrophilic tips that can bind with water molecules. Therefore, soap can bind with impurities, fat, and oil particles from the skin surface, and also can be rinsed by water (Gusviputri et al ., 2013). 
Furthermore, the bioactive compounds in seaweed could also promote the cleaning performance of the soap. For instance, saponin, one of the bioactive compounds in seaweed, can become a surfactant and therefore could have a cleaning ability (Gusviputriet al ., 2013).

Another sensory analysis that was tested in this study is the irritation test. The irritation characteristic of the soap can be caused by the remaining of caustic soda, as free alkali, which did not fully react to produce soap (Ismanto et al ., 2016). Moreover, the active compounds in the seaweed can also add to the alkalic condition of the soap. The curing process, which is a storage of soap for some time at room temperature, is usually applied in the soap making process to evaporate the alkalic compounds (Dyartanti et al ., 2014).

\section{Physicochemical analysis}

The physicochemical analysis was carried out to evaluate the quality of the bar soap variants, which is compared to the bar soap standard such as SNI 3532:2016 (Badan Standardisasi Nasional, 2016). As shown in Fig. 5, the bar soap of variant E750 has the highest $\mathrm{pH}$ (11.5). The ethanol in variant E750 may bind more bioactive compounds in seaweed, such as phenols, alkaloids, and flavonoids, compared to water solvent in other variants. These compounds provide more alkalic conditions and therefore increase the $\mathrm{pH}$ of the soap. Another possibility is that ethanol itself has higher $\mathrm{pH}$ compared to water, and therefore provides higher $\mathrm{pH}$ in the soap of variant E750. The indifference of $\mathrm{pH}$ between the other soap variants and controls could indicate the lower concentration of bioactive compounds dissolved in water compared to ethanol (Febriantoet al ., 2019). The $\mathrm{pH}$ standard of bath soap according to the Indonesian National Standard of liquid bath soap, SNI 4085:2017 is 4.0 - 10.0 (Badan Standardisasi Nasional, 2017). All of the bar soap variants in this study, excluding the variant E750, meet this requirement.

Fig. 6 shows that there is an increasing trend of foam stability between the bar soap variant of W250 (93.7\%), W500 (97.4\%), and W750 (97.9\%). This trend might occur due to the increasing of saponin content in the bar soap since saponin produces foam when in contact with water (Widyasanti et al ., 2016). Also, the bar soap variants in this study have higher foam stability $(93.7-98.9 \%)$ compared to the soap developed in the other study by Widyasanti et al . (2016), which is $36.35-59.36 \%$.

The total fat content in the bar soap variants, as can be seen in Fig. 7, might be mostly acquired from the fatty acids contained in palm and coconut oil. The examples of the fatty acids content are caprylic, capric, lauric, myristic, palmitic, stearic, oleic, and linoleic acid (Abast et al ., 2015). The bioactive compounds in seaweed, such as steroids, could also have a role in the total fat content of the soap (Febrianto et al ., 2019). However, the bar soap variants in this study do not yet meet the total fat standard according to the Indonesian National Standard for bar soap, SNI 3532:2016 (Badan Standardisasi Nasional, 2016). The total fat standard of bar soap should be more than $65 \%$, whereas the total fat content of the variants in this study is between $53.18-62.66 \%$. The lower total fat content indicates that the bar soap will wear off faster.

The unsaponifiable fat content in the bar soap variants is still higher than the standard requirement (Fig. 8). According to the Indonesian National Standard for bar soap, SNI 3532:2016, the unsaponifiable fat content in the bar soap should be lower than 0.5\% (Badan Standardisasi Nasional, 2016). The high unsaponifiable fat content indicates that the fatty acids were not fully converted to soaps by the saponification (Widyasanti et al ., 2016).

\section{Bioactivity analysis}

The bioactivity analysis was carried out to evaluate the anti-bacteria function of the bar soap variants. $S$. aureus was applied in this analysis since the bacteria is a common pathogen that infects the human's skin (McCaig et al ., 2006). The interesting part of the result, as can be seen in Fig. 9, is that the commercial antiseptic bar soap (C2) has lower bioactivity compared to the bar soap variants in this study. The bar soap C2 might not be made to hold the growth of $S$. aureus specifically, but perhaps it has higher bioactivity against other types of human skin's bacteria.

The additional of seaweed pulp in the bar soap (SWP) could increase the bioactivity against $S$. aureus since the inhibition index of SWP is higher than control (C1). The bioactivity is expected to come from the 
metabolites content of the seaweed. The seaweed pulp contains bioactive compounds, such as alkaloids, phenols, and flavonoids, which have anti-bacteria characteristics (Alves et al ., 2013; Cushnieet al ., 2014; Xie et al ., 2014; Bestari, 2018). On the other hand, the bar soaps with the addition of seaweed extract (W250, W500, W750, and E750) have lower bioactivity compared to control (C1). This is perhaps due to a lower concentration of bioactive compounds that were extracted from the seaweed to the solvent (water and ethanol). The extraction method, thus, requires optimization for further development to attain bar soap with higher bioactivity. For example, by considering other options for the extraction solvent such as ethyl acetate and acetone (Lestario et al ., 2008; Francavilla et al ., 2013).

To conclude, this study has developed bar soaps that enriched with seaweed G. verrucosa through the addition of seaweed extract (W250, W500, W750, and E750) and seaweed pulp (SWP). The bar soap of variant W500 has the highest preference value according to the sensory analysis. The variant W500 also has the physicochemical parameters that approach the standard requirement. While the variant SWP has the highest bioactivity. From the results, the bar soap of variant W500 and SWP can be the candidates for further product development. Some optimizations must be performed for further development, such as for the filtration of seaweed pulp and the extraction method. More tests should also be carried out in further studies to evaluate the quality of the bar soap according to the standard.

\section{Acknowledgments}

The authors would like to thank Polytechnic of Marine Affairs and Fisheries Karawang for funding this research.

\section{References}

Abast, M. A., Koleangan, H., and Pontoh, J. 2015. Analisis Asam Lemak dalam Minyak Kelapa Murni Menggunakan Derivatisasi Katalis Basa.Jurnal MIPA UNSRAT ONLINE, 5 (1), 29-31.

Alves, M. J., Ferreira, I. C., Froufe, H. J., Abreu, R. M., Martins, A., and Pintado, M. 2013. Antimicrobial Activity of Phenolic Compounds Identified in Wild Mushrooms, SAR Analysis and Docking Studies. Journal of Applied Microbiology, 115 (2), 346-357.

Badan Pusat Statistik Kabupaten Karawang. 2017. Kabupaten Karawang dalam Angka 2016 . Karawang, West Java, Indonesia: Badan Pusat Statistik Kabupaten Karawang.

Badan Pusat Statistik Kabupaten Karawang. 2018. Kabupaten Karawang dalam Angka 2017. Karawang, West Java, Indonesia: Badan Pusat Statistik Kabupaten Karawang.

Badan Pusat Statistik Kabupaten Karawang. 2019. Kabupaten Karawang dalam Angka 2018. Karawang, West Java, Indonesia: Badan Pusat Statistik Kabupaten Karawang.

Badan Standardisasi Nasional. 2016. SNI 3532:2016 Sabun Mandi Padat . Jakarta: Badan Standardisasi Nasional.

Badan Standardisasi Nasional. 2017. SNI 4085:2017 Sabun Mandi Cair . Jakarta: Badan Standardisasi Nasional.

Baehaki, A., Lestari, S. D., and Hildianti, D. F. 2019.Pemanfaatan rumput laut Eucheuma cottonii dalam pembuatan sabun antiseptik. Jurnal Pengolahan Hasil Perikanan Indonesia, 22 (1), 143-154.

Bestari, E. 2018. Karakteristik Bubur Rumput Laut Gracilaria verrucosa dan Turbinaria conoides Sebagai Bahan Baku Body Lotion. Bogor: IPB Repository.

Bramble Berry Inc. 2016. How to Use Alcoholic Beverages in Cold Process Soap . Retrieved from https://www.soapqueen.com/bath-and-body-tutorials/tips-and-tricks/how-to-use-alcoholic-beveragesin-cold-process-soap/

Bramble Berry Inc. 2019. Lye Calculator . Retrieved from https://www.brambleberry.com/calculator?calcType=lye 
Cushnie, T. P., Cushnie, B., and Lamb, A. J. 2014. Alkaloids: An Overview of Their Antibacterial, Antibiotic-Enhancing and Antivirulence Activities. International Journal of Antimicrobial Agents, 44 , 377-386.

de Almeida, C. L., Falcão, H. d., Lima, G. R., Montenegro, C. d., Lira, N. S., de Athayde-Filho, P. F., Rodrigues, L. C., de Souza, M. d. F. V., Barbosa-Filho, J. M., and Batista, L. M. 2011. Bioactivities from Marine Algae of the Genus Gracilaria . International Journal of Molecular Sciences, 12 , 4550-4573.

Deswati, R. H., and Luhur, E. S. 2014. Profil Budidaya dan Kelembagaan Pemasaran Rumput Laut (Grasillaria sp) di Kecamatan Muara Gembong, Kabupaten Bekasi, Jawa Barat. Buletin Ilmiah Marina Sosial Ekonomi Kelautan dan Perikanan, 9 (1), 31-34.

Dyartanti, E. R., Cristi, N. A., and Fauzi, I. 2014. Pengaruh Penambahan Minyak Sawit Pada Karakteristik Sabun Transparan.Ekuilibium, 13 (2), 41-44.

Febrianto, W., Djunaedi, A., Suryono, S., Santosa, G. W., and Sunaryo, S. 2019. Potensi Antioksidan Rumput Laut Gracilaria verrucosa dari Pantai Gunung Kidul, Yogyakarta. Jurnal Kelautan Tropis, 22 (1), 81-86.

Francavilla, M., Franchi, M., Monteleone, M., and Caroppo, C. 2013. The red seaweed Gracilaria gracilis as a multi products source. Marine Drugs, 11 (10), 3754-3776.

Gouda, S., Moharana, R. R., Das, G., and Patra, J. K. 2013. Free radical scavenging potential of extracts of Gracilaria verrucosa (L) (Harvey): An economically important seaweed from Chilika lake, India. International Journal of Pharmacy and Pharmaceutical Sciences, 6 (1), 707-710.

Gusviputri, A., Meliana, N., Aylianawati, and Indraswati, N. 2013. Pembuatan Sabun dengan Lidah Buaya (Aloe vera) sebagai Antisepti Alami. Widya Teknik, 12 (1), 11-21.

Hall, N. 2016. Implications of Soap Structure for Formulation and User Properties . In Soap Manufacturing Technology: Second Edition (pp. 1-33). London, UK: Elsevier Inc.

Hikmayani, Y., Aprilliani, T., and Zamroni, A. 2017. Analisis Pemasaran Rumput Laut di Wilayah Potensial di Indonesia. Jurnal Sosial Ekonomi Kelautan dan Perikanan, 2 (2), 159-175.

Hwang, P., Wu, C., Gau, S., Chien, S., and Hwang, D. 2010.Antioxidant and immune-stimulating activities of hot-water extract from seaweed Sargassum hemiphyllum. Journal of Marine Science and Technology, 18 (1), 41-46.

Ismanto, S. D., Neswati, and Amanda, S. 2016. Pembuatan Sabun Padat Aromaterapi dari Minyak Kelapa Murni (Virgin Coconut Oil) dengan Penambahan Minyak Gubal Gaharu (Aquilaria malaccensis ).Jurnal Teknologi Pertanian Andalas, 20 (2), 9-19.

Kaliaperumal, N. 2003. Products from seaweeds. SDMRI Research Publication, 3 , 33-42.

Karo Karo, A. Y. 2011. Pengaruh Penggunaan Kombinasi Jenis Minyak Terhadap Mutu Sabun Transparan. Bogor: IPB Repository.

Kim, S. W., Hong, C., Jeon, S., and Shin, H. 2015. High-yield production of biosugars from Gracilaria verrucosa by acid and enzymatic hydrolysis processes. Bioresource Technology, 196 , 634-641.

Kurniasari, K. D., Arsianti, A., Aziza, Y. A. N., Mandasari, B. K. D., Masita, R., Zulfa, F. R., Dewi, M. K., Zagloel, C. R. Z., Azizah, N. N. and Putrianingsih, R. 2018. Phytochemical analysis and anticancer activity of seaweed Gracilaria verrucosa against colorectal HCT-116 cells. Oriental Journal of Chemistry, 34 (3), 1257.

Lestario, L. N., Sugiarto, S., and Timotius, K. H. 2008. Antioxidant Activity and Total Phenolic Content of Red Sea Weed (Gracilaria verrucosa L.). Jurnal Teknologi dan Industri Pangan, 19 (2), 131-138. 
Maftuch, Kurniawati, I., Adam, A., and Zamzami, I. 2016. Antibacterial effect of Gracilaria verrucosa bioactive on fish pathogenic bacteria. Egyptian Journal of Aquatic Research, 42 (4), 405-410.

Mahyati, Badai, M., Yusuf, M., Pasanda, O. S., and Sofia, I. 2018. PKM Pelatihan Pembuatan Sabun Terapi dan Kesehatan dari Tanaman Sereh (Cymbopogon citratus) di Desa Sambueja Kecamatan Simbang Kabupaten Maros. Prosiding Seminar Hasil Pengabdian, 306-308.

McCaig, L. F., McDonald, L. C., Mandal, S., and Jernigan, D. B. 2006. Staphylococcus aureus -associated Skin and Soft Tissue Infections in Ambulatory Care. Emerging Infectious Diseases, 12 (11), 1715-1723.

Moloka Farm Living. 2019. Natural Soap Making - Cold Process Method . Jakarta: Moloka Farm Living.

Prasedya, E. S., Sunarpi, and Hamdin, C. D. 2018. Aplikasi Ekstrak Rumput Laut Sargassum sp Sebagai Produk Handsoap Lokal Pada Guru dan Siswa SD GMC Puyung Lombok Tengah. Prosiding PKMCSR, $1,564-571$.

Rahayu, S. 2015. Formulasi dan Evaluasi Mutu Fisik Sabun dari Ekstrak Rumput Laut Merah (Euchema cottoni ). Jurnal Wiyata, 2 (1), 14-18.

Razarinah, W. A., Ross, E. E., Rahim, N. F., Faridon, B. S., and Radzun, K. A. 2018. Antimicrobial Activity of Marine Green Algae Extract Against Microbial Pathogens. Malaysian Journal of Biochemistry and Molecular Biology, 2 , 42-46.

Setyaningsih, H., Sumantadinata, K., and Palupi, N. S. 2012.Kelayakan Usaha Budi Daya Rumput Laut Kappaphycus alvareziidengan Metode Longline dan Strategi Pengembangannya di Perairan Karimunjawa. Manajemen IKM, 7 (2), 131-142.

Tanjung, A., Wardani, A. K., Saputra, R. S., and Prasetyati, S. 2020. Pengaruh Penambahan Arang Aktif Terhadap Mutu Sabun Mandi Cair Rumput Laut (Gracilaria sp.). Pelagicus, 1 (1), 31-39.

Waluyo, W., Permadi, A., Fanni, N., and Soedrijanto, A. 2019. Analisis Kualitas Rumput Laut Gracilaria Verrucosa di Tambak Kabupaten Karawang, Jawa Barat. Grouper, 10 (1), 32-41.

Wang, H., Ooi, E. V., and Ang, P. O. 2008. Antiviral activities of extracts from Hong Kong seaweeds. Journal of Zhejiang University: Science B, 9 (12), 969-976.

Widyasanti, A., Farddani, C. L., and Rohdiana, D. 2016.Pembuatan Sabun Padat Transparan Menggunakan Minyak Kelapa Sawit (Palm Oil) dengan Penambahan Bahan Aktif Ekstrak Teh Putih (Camellia sinensis ). Jurnal Teknik Pertanian Lampung, 5 (3), 125-136.

Widyasari, A. 2010. Kajian Pengaruh Jenis Minyak dan Konsentrasi Gliserin Terhadap Mutu Sabun Transparan . Bogor: IPB Repository.

Xie, Y., Yang, W., Tang, F., Chen, X., and Ren, L. 2014. Antibacterial Activities of Flavonoids: Structure-Activity Relationship and Mechanism. Current Medicinal Chemistry, 22 (1), 132-149. 